NBER WORKING PAPER SERIES

\title{
MONETARY AND FISCAL THEORIES OF THE PRICE LEVEL: THE IRRECONCILABLE DIFFERENCES
}

\author{
Bennett T. McCallum \\ Edward Nelson \\ Working Paper 12089 \\ http://www.nber.org/papers/w12089
}

\author{
NATIONAL BUREAU OF ECONOMIC RESEARCH \\ 1050 Massachusetts Avenue \\ Cambridge, MA 02138 \\ March 2006
}

The authors are grateful to Christopher Allsopp, David Vines and an anonymous referee for comments on an earlier draft. Justin Hauke provided research assistance. The views expressed in this paper are those of the individual authors and do not necessarily reflect official positions of the Federal Reserve Bank of St. Louis, the Federal Reserve System, the Board of Governors, or CEPR. The views expressed herein are those of the author(s) and do not necessarily reflect the views of the National Bureau of Economic Research.

(C2006 by Bennett T. McCallum and Edward Nelson. All rights reserved. Short sections of text, not to exceed two paragraphs, may be quoted without explicit permission provided that full credit, including () notice, is given to the source. 
Monetary and Fiscal Theories of the Price Level: The Irreconcilable Differences

Bennett T. McCallum and Edward Nelson

NBER Working Paper No. 12089

March 2006

JEL No. E5, E6, D8

\begin{abstract}
The fiscal theory of the price level (FTPL) has attracted much attention but disagreement remains concerning its defining characteristics. Some writers have emphasized implications regarding interest-rate pegging and determinacy of RE solutions, whereas others have stressed its capacity to generate equilibria in which price level trajectories mimic those of bonds and differ drastically from those of money supplies. We argue that the FTPL attained prominence precisely because it appeared to provide a theory whose implications differ greatly from conventional monetary analysis; accordingly we review monetarist writings to identify the primary distinctions. In addition, we review recent findings concerning learnability - and therefore plausibility - of competing RE equilibria. These indicate that when FTPL and monetarist equilibria differ, the latter are more plausible in the vast majority of cases. Under Ricardian assumptions, necessary for clear distinctions, theoretical analysis indicates that fiscal and monetary coordination is not necessary for macroeconomic stability.

Bennett T. McCallum

Graduate School of Industrial Administration

Carnegie-Mellon University

Pittsburgh, PA 15213

and NBER

bm05@andrew.cmu.edu
\end{abstract}

Edward Nelson

Federal Reserve Bank of St. Louis

edward.nelson@stls.frb.org 


\section{Introduction}

The fiscal theory of the price level is a controversial and strongly unorthodox body of analysis developed primarily by Leeper (1991), Sims (1994), and Woodford (1994, 1995, 2001). The main critics have been Buiter (2002) and McCallum (1999, 2001, 2003a). ${ }^{1}$

One aspect of the latter's approach has been to contrast the fiscal theory's predictions regarding price level behavior with that of traditional monetarist doctrine. On that basis, it has been argued that the distinguishing feature of the fiscal theory is its prediction of "price level paths that are dominated by bond stock behavior and [are] very different from the path of the nominal money stock” (McCallum, 2003a, p. 647).

It must be acknowledged, however, that the issue of what actually constitutes the core message of the fiscal theory is not itself an area of general agreement. Woodford (2003a), for example, disputes the characterization of the fiscal theory given above, instead contending that the leading example of the fiscal theory involves an interest rate peg by the central bank. In that example, money and prices do move together. In addition, he argues that the main message of the fiscal theory is that the intertemporal government budget constraint can be "an important factor in determining inflation" (2003a, p. 1185, emphasis added), not necessarily the factor. Similarly, Gordon and Leeper (2005) emphasize, as the "prototype” or "conventional” fiscal theory, a model in which the fiscal policy specification matters for money and price level behavior, but in which money and prices do move together in equilibrium.

The purpose of the present paper is to discuss some key issues regarding the fiscal theory of the price level (FTPL) and to emphasize the usefulness of comparisons that involve sharp distinctions between FTPL and monetarist doctrine. We argue that only cases in which the price level path veers away from the path of the money stock should be regarded as reflecting a bona fide FTPL. The other scenarios described by fiscal-theory advocates amount to descriptions of the process of monetary accommodation of fiscal balances, a phenomenon fully reconcilable with standard monetary theory. To justify and emphasize this reconciliation, we provide a discussion of the treatment of fiscal policy in standard monetary analysis and in monetarist doctrine in particular. It is those versions of the fiscal theory that produce irreconcilable differences with orthodox monetary analysis that, we argue, have provided the impetus for the FTPL to attract widespread

\footnotetext{
${ }^{1}$ Other critical discussions include Kocherlakota and Phelan (1999) and, more recently, Arce (2004, 2005) and Niepelt (2004).
} 
attention; without them, the FTPL results would arguably be minor and obscure curiosities. As we discuss below, the variants of the FTPL based on interest-rate rules do depart in some exceptional cases from monetarist positions, notably on whether the stipulated monetary policy rule can insulate the money stock from fiscal influences. But they do not reproduce the strikingly aberrant behavior of prices and velocity generated by the FTPL with money stock rules.

In addition, building on recent discussions-notably ones concerning the learnability of FTPL equilibria (see Evans and Honkapohja, 2004; McCallum, 2003a; and Woodford, 2003a) — we also consider some arguments about the plausibility of the equilibria described by the FTPL, under both money stock and interest-rate rules. Such arguments tend predominantly to support the orthodox, monetarist view of price level determination.

Our discussion proceeds as follows. We first consider the fiscal theory of the price level in fairly generic terms starting from the traditional equation of exchange (Section 2). Then in Section 3 we consider the FTPL in a dynamic model consistent with optimizing behavior, and review the arguments developed in McCallum (1999, 2001, 2003a) for favoring the alternative, monetarist solution to the model. Some important doctrinal considerations are put forward in Section 4. Then Section 5 revisits recent results on interest-rate rules and the FTPL in light of the preceding discussion. Section 6 briefly considers issues pertaining to a “cashless” economy, and Section 7 concludes.

At the outset we should emphasize two premises that we maintain throughout. First, our entire discussion takes place in a framework where Ricardian equivalence results typically hold. As stressed by Woodford (1995, p. 5), the importance of fiscal policy in the FTPL does not arise from the use of models well known to generate violations of Ricardian equivalence-e.g., finite-horizon models or ones with distorting taxes-and so it is appropriate to examine the debate on the FTPL under conditions such that Ricardian equivalence typically prevails. ${ }^{2}$ Second, in discussing alternative theories of the price level, our analysis is conditional on there being an inherited, initial price level. Thus, rival theories will be contrasted in terms of the solutions they provide for the price level for period 1-the policy's period of initiation —and in subsequent periods, conditional on the period 0 price level. This assumption means, in effect, that the expression for the constant term in the solution for the price level is provided by the initial condition, and

\footnotetext{
${ }^{2}$ This strategy does not imply that we consider analysis of fiscal-monetary interactions in a non-Ricardian (e.g., overlapping-generations) setup to be uninteresting or unimportant.
} 
does not need to be provided by the monetary policy rule. By making this assumption, we can focus on what alternative theories claim are the implications of alternative policy rules for price level dynamics, or, equivalently, for the inflation rate.

\section{The FTPL and velocity behavior}

In this section we provide an overview of the alternative implications of the monetary and fiscal theories for the money/price-level relationship, prior to considering more detailed models in Section 3. Let us start with the equation of exchange, $M V=P Y$, expressed in logarithmic form as:

$m_{t}+v_{t}=p_{t}+y_{t}$

where $m=\log$ nominal stock of money, $v=\log$ velocity of circulation, $p=\log$ price level, and $y=\log$ output (real GDP). As is well known, the equation of exchange is a model-free identity as long as no structure is imposed on velocity behavior. Using it as a starting point can nevertheless help to emphasize implications of structural models, in particular the version of the FTPL that we will focus upon. That FTPL variant implies unbounded discrepancies between $m$ and $p$. In equation-of-exchange terms, the FTPL can then be thought of as an attempt to provide a model that can generate explosive behavior of velocity-indeed, velocity explosions that occur even when the nominal money stock is held constant. ${ }^{3}$ Earlier generations of the monetary-vs.-fiscal-policy debate also delivered as limiting cases models that generated explosive velocity behavior, but arising from a source quite different from that used in the FTPL. We now provide some intuition for how the requisite explosion of velocity is produced in the FTPL framework.

Standard theories of money demand, including those used in the dynamic optimizing macroeconomic models typically employed in the FTPL literature, do impose structure which typically implies a velocity equation of the form $v_{t}=\theta_{0}+\left(1-\theta_{y}\right) y_{t}+\theta_{R} R_{t}$, where $\theta_{y}$ is the income elasticity of money demand and $\theta_{R}>0$ is the negative of the semielasticity of money demand with respect to the rate of return on nominal short-term securities (assumed to be the alternative financial asset to money). With this structure

\footnotetext{
${ }^{3}$ In the terminology of Kocherlakota and Phelan (1999, p. 21), such explosions amount to "purely speculative time trends in velocity.”
} 
imposed and on rearrangement, the equation of exchange yields a familiar demand function for real money balances: ${ }^{4}$

$m_{t}-p_{t}=-\theta_{0}+\theta_{y} y_{t}-\theta_{R} R_{t}$

It is convenient also to take output $\left(y_{t}\right)$ as fixed at its potential value $y^{f}$. While such an assumption creates a great loss of generality in other contexts, this is not the case for this discussion of the distinction between the FTPL and standard monetary theory. Monetary and fiscal theories of the price level essentially differ on what factors trigger expansion of nominal aggregate demand, not on how excess demand pressures are transmitted to the inflation rate. The rival theories can accordingly be presented using the same specification of the Phillips curve. To that end, it is convenient to impose the assumption of price flexibility — so that output follows an exogenous path. Indeed, such a treatment has been standard in the literature that developed the FTPL, including Leeper (1991) and Woodford (1995). And with potential output exogenous, nothing crucial to the exposition of the FTPL is lost by abstracting from fluctuations in potential output altogether. Then the first-differenced counterpart of (2) becomes

$g^{m}{ }_{t}-\pi_{t}=-\theta_{R} \Delta R_{t}$,

where $g^{m}{ }_{t}=\Delta m_{t}$ is money growth and $\pi_{t}=\Delta p_{t}$ inflation. These simplifications reveal that there are only two basic channels through which substantial, sustained divergences between $m_{t}$ and $p_{t}$ can occur. Arbitrarily large divergences of prices from money (and money growth from inflation) can occur if $\theta_{R}$ is infinite, or if $R_{t}$ exhibits explosive behavior. Of these two channels, one is not used at all by the FTPL, while the second is only used in some variants of the FTPL.

The case of $\theta_{R}=\infty$, an infinitely interest-elastic money demand function, was known in the early Keynesian literature and monetarism-vs.-Keynesianism debate as "absolute liquidity preference. ${ }^{\circ 5}$ Under such a parameter restriction, the slightest incipient movement in nominal interest rates produces an arbitrarily large movement in real money balances in the opposite direction. With log real balances being, by definition, the percentage deviation of the nominal money stock relative to the nominal price level,

\footnotetext{
${ }^{4}$ Quantitative applications might interpret this relationship as a long-run demand function and augment it with a serially correlated money demand shock or other sources of dynamics.

${ }^{5}$ See, e.g., McCracken (1950, p. 44) and Friedman (1970, p. 206).
} 
absolute liquidity preference implies that these two series can move arbitrarily far apart indefinitely. The effect of this model setting is to remove any relationship between nominal money and nominal spending that would otherwise be implied by the money demand specification. Equivalently, velocity can increase explosively even when its determinants do not. Central bank actions on the nominal money stock then have no implications for the levels of nominal aggregate demand and prices. In the early Keynesian literature, the $\theta_{R}=\infty$ case was interpreted as leaving scope for fiscal policy, via regulation of “autonomous” expenditure, to determine nominal aggregate demand completely independently of monetary policy.

It is a characteristic feature of the FTPL literature, however, that it does not rely on this or any other nonstandard specification of money demand. Accordingly, the money demand specification typically employed in FTPL work is close to the basic specification (2), with $\theta_{R}$ finite - and so, under our simplifying assumptions in this section, equation (3) will hold too. Arbitrary divergences between money and prices can then only occur in equilibria that produce explosive behavior of the nominal interest rate. To see the impact of the latter, let us insert the Fisher relationship $R_{t}=r_{t}+\mathrm{E}_{t} \pi_{t+1}$ into the firstdifferenced equation (3), obtaining

$g^{m}{ }_{t}-\pi_{t}=-\theta_{R} \Delta r_{t}-\theta_{R} \mathrm{E}_{t} \Delta \pi_{t+1}$

where $\Delta r_{t}$ is the first difference of the real interest rate. For the analysis here, it is legitimate to abstract from the $\Delta r_{t}$ term. Optimizing models provide little scope for anything other than transitory and/or one-time movements in real interest rates; thus, ongoing growth in the short-term real rate can be ruled out. ${ }^{6}$ Suppressing the real-rate term, then, we have

$g^{m}{ }_{t}-\pi_{t}=-\theta_{R} \mathrm{E}_{t} \Delta \pi_{t+1}$,

which would appear to be an expectational difference equation for inflation. As the only other variable besides inflation in this relationship is the money stock, the equation would appear to provide support for the monetarist proposition that money growth is the sole financial variable that matters for inflation dynamics. Indeed, for an exogenous money

\footnotetext{
${ }^{6}$ Precise constancy of the real interest rate and output would occur in the absence of shocks to taste and technology in the flexible-price economy; otherwise, the $\Delta r_{t}=0$ assumption is an approximation justified by the fact that $\Delta r_{t}$ should fluctuate around zero.
} 
growth path, this equation — or its levels counterpart—has been frequently studied as the expression for inflation dynamics implied by the Cagan (1956) money demand function, and has a "fundamentals" solution whereby inflation depends on the expected path of money growth. ${ }^{7}$ With a constant money growth rule, we would not have to consult any other equations that might appear along with equation (5) in a model to find the minimum state variable (MSV) solution for inflation, to use the terminology of McCallum (1983). Rather, by inspection of (5), the MSV solution is $\pi_{t}=0$ for all $t$ when money growth $g^{m}{ }_{t}$ is zero each period - that is, the price level is constant. Or, more generally, if $g^{m}{ }_{t}=g^{m}$, then also $\pi_{t}=g^{m}$. The MSV solution thus reflects the traditional "monetarist" result that inflation rates (and price levels) ${ }^{8}$ are pinned down by monetary policy, their constancy arising from the assumed constant money stock as well as the suppression, in this presentation, of fluctuations in the natural output level and the real interest rate. ${ }^{9}$

The FTPL alternative would instead suggest quite a different interpretation of the implications of a constant money stock. Setting $g^{m}{ }_{t}=0$, and considering the resulting expression

$\pi_{t}=\theta_{R} \mathrm{E}_{t} \Delta \pi_{t+1}$

the FTPL would not lead one to conclude that $\pi_{t}=0$ for all $t$, the solution suggested by standard monetary analysis, but instead that the price level is essentially determined by a different (and heretofore ignored) equation of the model. Instead of being sufficient to solve for prices, equation (6) instead describes one equilibrium condition that price-level and inflation dynamics must satisfy. In particular, they should have an explosive character-i.e., inflation and the expected change in inflation must explode together in just the manner required to balance the left and right hand sides of equation (6). The existence of a well-defined money demand function in this model ceases to guarantee that money growth and inflation move together in equilibrium. Indeed, in the FTPL, the government budget constraint is the key equation for solving for the price level, and prices explode in manner that mirrors the explosive behavior of the nominal bond stock.

\footnotetext{
${ }^{7}$ See, e.g., Sargent and Wallace (1973) and Evans and Honkapohja (2003).

${ }^{8}$ As discussed in Section 4 below, monetarist doctrine does allow nonmonetary factors to affect the price level, while insisting that the inflation rate is a monetary phenomenon. In the simplified presentation here, however, the monetarist position would be that both the price level and inflation are monetary phenomena. ${ }^{9}$ The solution for the price level is $p=m+\theta_{0}-\theta_{y} y^{f}+\theta_{R} r$, with $r$ and $m$ the constant values of the real rate and the money stock.
} 
Finally, to anticipate our discussion of interest-rate rules in Section 5, we note that some FTPL advocates, including Woodford (2001, 2003a), place emphasis on equilibria that emerge under a policy of nominal interest rate pegging. Whatever the other features of those equilibria, it is clear that with the short rate $R_{t}$ pegged at $R$, the simplified money demand equation (2) becomes:

$$
m_{t}-p_{t}=\theta_{y} y^{f}-\theta_{0}-\theta_{R} R
$$

and so we have

$g^{m}{ }_{t}=\pi_{t}$.

Money and prices do not diverge in such equilibria; indeed, under the simplifications used here (no shocks or dynamics, and flexible prices), money growth and inflation match one another each period. Such an outcome, of course, is not a violation of monetarist predictions about money growth-inflation relations at all. This accounts for our depiction of FTPL results with money stock rules as constituting the heart of the FTPL. Before pursuing this point, however, let us consider in greater detail the FTPL with money stock rules.

\section{The FTPL with an exogenous money stock}

The examination of the FTPL in McCallum (1999, 2001) as well as those of other commentators such as Kocherlakota and Phelan (1999), Carlstrom and Fuerst (2000), and Christiano and Fitzgerald (1999), focused on cases with monetary policy specified in terms of a money stock rule-for simplicity, a constant money stock. That approach was consistent with some notable work by FTPL advocates, including Sims (1994) and Woodford (1995, p. 14), which featured cases with a constant-money-stock rule, and which obtained solutions in which the price level and the nominal bond stock exploded but the real bond stock was stationary. Thus, these results featured the price level behaving like the nominal bond stock, not the quantity of money.

McCallum (1999, 2001, 2003a) took this case as the hallmark of the FTPL and argued that there is another model solution, with more traditional properties. ${ }^{10} \mathrm{~A}$ simplified

\footnotetext{
${ }^{10}$ Kocherlakota and Phelan (1999) reached a similar conclusion on more formal grounds.
} 
version of these results may be useful. Let the money demand function be

$m_{t}-p_{t}=-\theta_{0}+\theta_{y} y_{t}-\theta_{R} R_{t}+v_{t}=\gamma+\alpha\left(\mathrm{E}_{t} p_{t+1}-p_{t}\right)$

with $\alpha=-\theta_{R}<0$. Again we suppress variation in output, the real rate, and the money demand shock to focus on differences between theories. The government budget constraint (GBC) in this setup is:

$P_{t}\left(g_{t}-t x_{t}\right)=M_{t+1}-M_{t}+\left(1+R_{t}\right)^{-1} B_{t+1}-B_{t}$,

where $g_{t}$ and $t x_{t}$ are real government purchases and (lump sum) tax collections, respectively. In real terms, the GBC is:

$g_{t}-t x_{t}=\left(M_{t+1}-M_{t}\right) / P_{t}+\left(1+r_{t}\right)^{-1} b_{t+1}-b_{t}$,

where $b_{t}=B_{t} / P_{t}$. (Note our mixed notation for lower-case variables: $b_{t}=B_{t} / P_{t}$ is a real quantity, while, as before, $m_{t}=\log M_{t}$ is a log nominal quantity.) With $M_{t}$ constant and $r_{t}$ $=\rho$, we have

$b_{t+1}=(1+\rho) b_{t}+(1+\rho)\left(g_{t}-t x_{t}\right), \quad t=1,2, \ldots$

Since $1+\rho>1.0$, if $g_{t}-t x_{t}$ is constant then $b_{t}$, the real quantity of debt, explodes - unless somehow in period $1 b_{1}$ takes the unique value $-(1+\rho)(g-t x) / \rho$ that is consistent with stationarity. That is what the FTPL says will happen; that in period $t=1, B_{1}$ is given from the past and that period's general price level $P_{1}$ jumps to make $B_{1} / P_{1}=-(1+\rho)(g$ $-t x) / \rho$. It is also assumed that $t x-g>0$.

What about the price level in subsequent periods? With $m_{t}=m$, the money demand function

$m-p_{t}=\gamma+\alpha\left(\mathrm{E}_{t} p_{t+1}-p_{t}\right)$

can be solved for $p_{t}$. To solve this expectational difference equation, let us conjecture a solution that

$p_{t}=\phi_{0}+\phi_{1} p_{t-1}$, 
even though $p_{t-1}$ is extraneous (i.e., the lagged price level is not in equation (13), and thus is not a state variable according to the MSV solution criterion). Then $\mathrm{E}_{t} p_{t+1}=\phi_{0}+\phi_{1}\left(\phi_{0}\right.$ $\left.+\phi_{1} p_{t-1}\right)$ and

$m-\gamma=\alpha\left[\phi_{0}+\phi_{1}\left(\phi_{0}+\phi_{1} p_{t-1}\right)\right]+(1-\alpha)\left[\phi_{0}+\phi_{1} p_{t-1}\right]$.

Thus $0=\alpha \phi_{1}{ }^{2}+(1-\alpha) \phi_{1}$ implies that $\phi_{1}=0$ or that $\phi_{1}=(\alpha-1) / \alpha$. The traditional (and MSV) solution is $\phi_{1}=0$, but FTPL writers such as Sims (1994) emphasize instead $\phi_{1}=$ $(\alpha-1) / \alpha>1$. Thus $p_{t}=[(\alpha-1) / \alpha] p_{t-1}$ in their solution, $P_{t}$ grows explosively, andwith $b_{t}$ constant—so does $B_{t}$. That is the FTPL outcome.

The "monetarist" solution, by contrast, is that $P_{t}$ grows at the rate 0 (since $\phi_{1}=0$ ) and $B_{t+1}$ $=0$ for $t=1,2, \ldots$, since $b_{t}$ growing at rate $\rho$ would violate a transversality condition necessary for optimality. Consistency of the latter with the usual FTPL assumption that fiscal policy specifies a constant, positive fiscal surplus relies upon an equilibrium condition in which government bond demand is less than or equal to bond supply; for development of this argument, see McCallum (2001, 2003a).

Both of these are algebraically legitimate rational expectations solutions; but which is plausibly realistic? McCallum (1999, 2001) argued that the FTPL solution relied upon a "bubble" solution - that is, it introduced an extraneous state variable (here, $p_{t-1}$ ) into the solution expressions. That variable is extraneous in the sense that an examination of the model equations would not justify specifying $p_{t-1}$ as one of the predetermined variables that appears in the structure of the model. It would therefore not be included the list of state variables when solving the model by the minimum state variable procedure, implying that equilibria in which $p_{t-1}$ does enter are "non-fundamental" solutions and therefore are arguably dubious. In this regard, we will consider important arguments from the recent literature in Section 5.

For now, it is sufficient to note that the above outline of the FTPL shares the perspective of several commentators in emphasizing the characteristic that the price level in the FTPL can be driven by a fiscal variable even when the money stock is constant. It is also in line with the position of Woodford (1995, p. 25) that the contrast between traditional and FTPL doctrine should be brought out by examples in which the stocks of money and government debt diverge. We will reaffirm that this is indeed the area where the debate between orthodox and fiscal theories should be focused. The great attention that interest- 
rate rules have received in the FTPL literature suggests that this should not be taken as an area of general agreement. But, as a theory that contrasts with monetarist doctrine, the unorthodox aspects of FTPL are limited to those versions of the FTPL that occur with money stock rules. The link between fiscal policy and inflation that arises in the FTPL under interest-rate pegs or other "passive” monetary policy rules does not contradict the key messages of monetarism. We illustrate this point in the next two sections: first with a tour through the record of what monetarist doctrine said about fiscal policy, then a discussion of some of the FTPL literature's results on interest-rate rules.

\section{Doctrinal considerations}

McCallum (2003a, p. 634) argues that the FTPL should be characterized as a theory that produces an equilibrium whose price level path is dominated by the behavior of the stock of government bonds, with the resulting price behavior "entirely unlike" that of the nominal stock of money. As noted above, prominent advocates of the fiscal theory prefer to define the theory differently, so as to cover cases where the money stock and price level actually do move together. In particular, an example emphasized in much of the FTPL literature is one in which the central bank stabilizes the nominal interest rate, permitting it to exhibit only a weak response to inflation. The scenario studied is where the stabilization of the nominal interest rate takes place in the face of an expanding government debt stock, leading to growth in both the money stock and the nominal price level. Woodford (2003a, p. 184) argues that the limiting case of such a scenario-an interest-rate peg-is the "leading example" of the fiscal theory, while Gordon and Leeper (2005, pp. 3, 20) similarly argue that interest-rate stabilization provides the basis for the "benchmark exposition of the fiscal theory," since in their definition the "conventional [fiscal] theory... does not hold fixed the path of the nominal money stock." In the paragraphs below, we argue that doctrinal considerations argue against defining the FTPL in a manner that views the rate-pegging example as the prototype version of the theory.

The essential problem with describing the fiscal theory with examples of interest-rate stabilization alongside fiscal expansion, and consequent growth in money and prices, is that such phenomena do not contradict key aspects of the orthodox analysis of price level determination. The FTPL does give different answers from standard analysis about the particular equilibrium that arises from interest-rate rules in some cases, as we discuss in the next section. But even in these FTPL equilibria, money growth and inflation move together closely. In those cases, therefore, the FTPL can be regarded as an account of 
how excessive monetary expansion comes about, not as an alternative to the monetary explanation of inflation.

The possibility that excessive money creation might arise from fiscal deficits was well recognized before the FTPL literature. In particular, the likelihood that an explosive government debt path would eventually trigger monetary expansion was an important message of Sargent and Wallace (1981). Possibly as a consequence, the early debates on the fiscal theory seemed to take as common ground that the FTPL is not closely related to the phenomena discussed by Sargent and Wallace (1981), in which fiscal policy comes to dominate monetary policy behavior. ${ }^{11}$

Furthermore, we will argue that the general recognition of deficit/money growth connections has a long doctrinal background preceding Sargent and Wallace: that in fact, "cases in which monetary policy is accommodating fiscal policy requirements... are fully consistent with traditional monetary analysis ... [and] monetarist doctrines" (McCallum, 2003a, p. 645). Indeed, since the emphasis in McCallum $(1999,2001)$ and Kocherlakota and Phelan (1999) is on contrasting monetarist doctrine with the fiscal theory of the price level, it is worth discussing in detail what monetarism had to say about monetary-fiscal interaction. We will see in what sense monetarism did and did not assign importance to fiscal policy, both in its positive and normative analysis. A very relevant previous discussion is that in Woodford (2001), who opens his paper with a quotation from a prominent monetarist (Brunner, 1986, p. 54) suggesting that "proposals for a monetary rule require a supplementary proposal for a fiscal rule," a statement that on the surface might seem to lend some support to the FTPL literature. The analysis below is intended to shed light on precisely what role monetarist doctrine assigned to monetary-fiscal policy coordination.

In determining representative "monetarist" positions on the role of fiscal policy in price level determination and policy-rule formulation, we consider the statements on the subject by the core monetarists: Milton Friedman, Anna Schwartz, Karl Brunner, and Allan Meltzer. Our discussion of monetarist doctrine considers four issues regarding monetary-fiscal interaction: (A) curbing inflation; (B) the influence of fiscal policy on

\footnotetext{
${ }^{11}$ This characterization of the FTPL is thus different from that given by Gordon and Leeper (2005, p. 3) who argue that the FTPL describes situations where "fiscal obligations constrain monetary policy," as in Sargent and Wallace (1981).
} 
monetary policy; (C) the effect of fiscal expansion; and (D) the status of monetary-fiscal policy coordination.

A. Curbing inflation. Friedman stated the archetypal monetarist position on fiscal policy in 1981:

I don't think monetary policy has to be backed up by fiscal policy at all. I think monetary policy can curb inflation. ${ }^{12}$

Similarly Meltzer (1977, p. 99) observes:

In principle, monetary policy can restore price stability even if the government continues to run large deficits.

Thus, in the monetarist view, monetary restraint is both necessary and sufficient to control inflation.

B. Role of fiscal expansion in producing monetary expansion. A useful entry point to the monetarist position on the connection between fiscal and monetary expansion is the discussion by Friedman (1987) of the link between fiscal expansion and inflation:

Government spending may or may not be inflationary. It clearly will be inflationary if it is financed by creating money... If it is financed by taxes or by borrowing from the public, the main effect is that the government spends the funds instead of the taxpayer or instead of the lender or instead of the person who would otherwise have borrowed the funds. (Friedman, 1987, p. 17).

Therefore, according to monetarist doctrine, there is no connection between deficit creation and inflation in principle. Nevertheless, Friedman also observes that, in practice:

Essentially all major inflations, especially hyperinflations, have resulted from resort by governments to the printing press to finance their expenditures under conditions of great stress such as defeat in war or internal revolution... (Friedman, 1987, p. 17).

These wartime conditions correspond most closely to the experiment of "printing money" to finance a deficit, i.e., of the central bank purchasing directly the debt issued by the government. Monetarists have observed that in peacetime practice, the more likely

${ }^{12}$ Quoted in Larsen (1981). 
conditions for deficits to trigger money creation occur if the central bank pegs or stabilizes the nominal interest rate, thereby offsetting pressure on the nominal interest rate that arises from deficits. Brunner (1977, p. 167), for example, has noted that "[a]n interest target policy explains, moreover, the persistent association between the magnitude of the budget deficit and the growth rate of the monetary base," while Friedman (1978a) notes that "pressures... to finance government spending and to keep interest rates low are a major reason for high monetary growth.” (See also Friedman and Schwartz, 1963, Ch. 10.)

Monetarists see little analytical distinction between direct and indirect monetization of the deficit. Brunner (1976, p. 36) notes that it is "actually immaterial whether the government obtains a variety of direct or indirect advances from the central bank or whether the central bank only purchases securities on the open market," while Meltzer (1977, p. 100) observes that interest-rate stabilization constitutes a "roundabout, indirect way of financing the deficit [which] produces as much inflation as a conscious decision on the part of the Federal Reserve to print money for the Treasury.” It is the monetarists' acknowledgement of the effects of interest-rate pegging on money growth that makes the rate-pegging example an inappropriate tool with which to describe the fiscal theory of the price level.

Monetarist analysis recognizes the importance of factors other than fiscal policy as sources of money growth. For example, Friedman (1978b, p. 26) qualifies his discussion of deficits with the observation:

Fiscal policy may play an important role in producing and curing inflation. Its influence is primarily through its effect on the quantity of money. But its influence can be offset by other forces affecting the quantity of money. Large government surpluses in the USA in 1919 and 1920 did not prevent rapid inflation because they were accompanied by rapid monetary growth which financed private spending. Large government deficits in the USA in 1931 to 1933 did not produce rapid inflation or prevent severe deflation because they were accompanied by a sharp decline in the quantity of money which sharply reduced private spending.

Friedman has emphasized that these divergences are a general feature of the peacetime U.S. experience:

deficits have a direct effect on inflation when they are financed by creating money (as they were in the two world wars). But wartime periods aside, many other factors typically affect the rate of monetary growth, so that there is only the loosest relation in practice between monetary growth and deficits. (Friedman, 1981). 
Similarly, Brunner (1969) observes: “There are occurrences of inflations without large budget deficits and very large changes in deficits with no visible effect on the broad behavior of the economy.” Meltzer (1976, p. 189) has argued that such a loose pattern extends even to certain hyperinflations:

Central banks are able to produce inflation without a budget deficit. Take the great German inflation of the 1920s... Much of that inflation was produced by giving credit to the private sector... We have inflation where the government budget is financed by printing money. We have inflation where the private sector is financed by printing money.

Taken together, these quotations present a consistent picture of the monetarist position. Monetarists by no means denied the existence of pressure to monetize fiscal deficits, and accepted that such monetization was an implication of interest-rate pegging; but they also emphasized that other monetary policy-rule choices can insulate money growth from deficit creation. Monetary restraint is thus feasible in the presence of fiscal expansion; and equally, both moderate and large inflations can arise from policies that generate high money growth even in the absence of deficit spending.

C. Effects of fiscal expansion without monetary expansion. What is the consequence, in the monetarist view, of fiscal expansions that do not trigger higher money growth? Meltzer (1984, pp. 121-122) contends:

There is no evidence that temporary deficits are inflationary unless they are financed, directly or indirectly, by faster money growth. There is considerable evidence that large, persistent deficits cannot be financed without inflation.

The reference here to "directly or indirectly" pertains to the consequences of an interestrate pegging policy, noted above.

Monetarists do acknowledge that, for given money growth, fiscal expansion can place upward pressure on real and so nominal interest rates, and thereby raise the opportunity cost of holding money. Such a shift means that nominal spending rises even when the nominal money stock is held constant. Thus, Brunner (1975, p. 95) observed: “An explosion of government debt financing raises the long-run level of velocity.” As has been frequently noted, however, ${ }^{13}$ this real interest rate/money demand channel does not constitute the link between fiscal expansion and inflation underpinning the fiscal theory of the price level, so monetarist and fiscalist theories cannot be reconciled via this route.

${ }^{13}$ See e.g. Walsh (2003, p. 165). 
Moreover, the money demand channel does not preclude a purely monetarist view of inflation determination, in light of the monetarist distinction between inflation and onetime shifts in the price level. Brunner and Meltzer (1975), for example, observe:

The conditions for steady, long-run fiscal inflation are unlikely to be met in practice. Adjustments to fiscal change can produce higher or lower price levels, not steady inflation or deflation. To reach higher levels, prices must rise, and the rate of change can persist for some time... [T] $[$ he rate of price change... declines to zero as the economy adjusts to the fiscal position. (Brunner and Meltzer, 1975, p. 42).

It was the lack of support that the opportunity-cost/velocity channel provides for sustained inflation that led Brunner (1980) to conclude: “[T]he level of deficits, large and small, exert[s] per se (that is, irrespective of the feedback via money creation) no effect on the rate of inflation." It should be noted also that even the price level effect of fiscal expansion is weakened to the extent that agents have infinite horizons and perceive the fiscal operation as permanent; in that case, private consumption adjusts downwards and the real interest rate becomes less sensitive to fiscal policy.

D. Monetary-fiscal policy coordination. The role of monetary-fiscal policy coordination in monetarist analysis is implied by the following observations by Friedman (1987):

Fiscal policy is extremely important in determining what fraction of total national income is spent by government and who bears the burden of that expenditure. It is also extremely important in determining monetary policy and, via that route, inflation. (Friedman, 1987, p. 17).

Specifically on deficits, Friedman has noted:

In an economic sense, the budget is always balanced. The only question is how the total tax is divided between open and above-board taxes... and hidden taxes...

and Friedman distinguishes between two types of "hidden tax," only one of which is inflationary:

Insofar as it [the deficit] was financed by printing money, we paid for it by the hidden tax of inflation; insofar as it was financed by borrowing, we paid for it in the form of an even more subtle hidden tax on wealth. (Friedman, 1984).

On a similar note, Schwartz (1985) observes: 
Coordination of debt management by the Bank [i.e., the monetary authority] and the needs of the Exchequer [i.e., the fiscal authority] is clearly desirable. The question is how to formulate an arrangement that recognizes the basic choice to be [between] financing government expenditures by the tax on money balances (implicit in the inflationary creation of money for government purposes), by taxation in other forms, or by borrowing at home or abroad at whatever interest rates are necessary.

In particular, she notes that the coordination should recognize that attempting to peg or administer interest rates on government debt in the face of deficits will imply an expanding money stock and so will be "at the cost of changes in the general price level" (Schwartz, 1985, p. 100).

In 1980, the Shadow Open Market Committee, at the time including Brunner, Meltzer, and Schwartz in its membership, characterized the importance of fiscal policy in the following terms:

Fiscal expansion makes anti-inflation monetary policy less credible by increasing the size of the budget deficit, raising real interest rates and adding to the widespread belief that the Federal Reserve will finance the deficit by raising money growth... (1980, p. 384).

Importantly, these observations are prefaced by the statement: "Monetary policy can end inflation without a supporting fiscal policy” (1980, p. 384).

Thus, the normative prescriptions of prominent monetarists did assign a role to fiscal policy in demand control. But that role was limited to $(a)$ an explicit recognition by the government that it had to choose between different methods of financing of its spending, one of which (money creation) implied a choice of the inflation rate, and (b) creation of debt-management and deficit-control arrangements that restrain fears of monetary accommodation, either now or in the future. Neither of these policy prescriptions rests on, or endorses, the message of the fiscal theory that the debt path matters for the path of the price level irrespective of any feedback of government debt onto money creation.

On the basis of the above sketch of monetarist doctrine, it seems appropriate to summarize it as:

(I) A restrictive monetary policy can cure inflation even in the absence of fiscal restriction. 
(II) Fiscal expansion produces inflationary pressure insofar as it is accommodated by monetary policy, or is expected to be accommodated in the future. In practice, several major inflations have reflected monetization of deficits; but some moderate and major inflations have been due to inflationary monetary policies that have occurred without major fiscal deficits.

(III) Fiscal expansion in the face of monetary restriction does not produce inflationary pressure.

(IV) Proposals for a monetary policy rule require a fiscal policy rule, as stated in the Brunner (1986) passage that Woodford (2001) highlights. But the implied requirement is only that fiscal arrangements should not impose any automatic obligations on the part of the central bank to monetize government debt. ${ }^{14}$ This coordination obligation does not overturn the result that the monetary policy rule alone determines the inflation rate; indeed, it is the mirror image of the monetarist position that fiscal policy matters for inflation only via its effect on money creation.

\section{Interest-rate rules and the FTPL}

Let us now reconsider some of the discussion of interest-rate rules that has taken place in the FTPL literature. A useful starting point is Leeper’s (1991) argument that monetary and fiscal policy coordination was needed for model "determinacy," that is, a single, dynamically stable rational expectations solution. He worked (in a standard flexibleprice model) with monetary and fiscal rules as follows:

$R_{t}=\mu_{0}+\mu_{1} \pi_{t}$

$t x_{t}=\tau_{0}+\tau_{1} b_{t}$

i.e., with the central bank conducting policy with an interest-rate rule that responds to current inflation, and with the fiscal authority's (lump-sum) real tax collections $\left(t x_{t}\right)$ being set in response to the real stock of government bonds outstanding. Leeper defined monetary policy to be "active" if $\left|\mu_{1}\right|>1+\rho$ and "passive" otherwise-AM vs. PM-and fiscal policy to be "passive" if $\rho<\tau_{1}<2+\rho$ and "active” otherwise (PF vs. AF).

\footnotetext{
${ }^{14}$ In the words of Brunner and Meltzer (1993, p. 127): “A viable non-inflationary monetary regime requires severe constraints on the fiscal regime.”
} 
Leeper's results regarding determinacy are summarized in Figure 1, which is based on Evans and Honkapohja (2004). Note that if both monetary policy and fiscal policy are passive, indeterminacy prevails, while if both are active there is no stable rational expectations solution.

Note also that $\mu_{1}>1+\rho$ approximately corresponds to the "Taylor principle" regarding the policy response of the nominal interest rate to inflation, which most analysts would take to be necessary for a sensible $R_{t}$ policy rule. ${ }^{15}$ Thus Leeper terms as "active" a monetary policy that we would characterize as sensible.

For fiscal policy, Leeper's terminology is in a sense reversed, for fiscal policy is called passive if $\rho<\tau_{1}<2+\rho$, and active otherwise. Our point is that, within this region, $\rho<\tau_{1}<1+\rho$ is the parameter range where fiscal policy tends to retire a positive fraction of government debt each period (in the absence of government revenue provided by monetary policy) - i.e., to be stabilizing. In this case, fiscal policy would be behaving sensibly, so as to stabilize the amount of government debt outstanding-rather than letting it grow explosively (if $\tau_{1}<\rho$ ) or paying off more than the outstanding debt in one period (if $1+\rho<\tau_{1}$ ). Thus we see that sensible fiscal policy is labeled "passive," while sensible monetary policy is called "active."

Terminology aside, Sims (1994) and Woodford (1995) adopted Leeper's policy specification and concluded that a determinate solution could be obtained with $\mu_{1}=0$ (i.e., a pegged $R_{t}$ ) if fiscal policy was active, and also that monetary-fiscal coordination was needed. Woodford (1995, p. 35) argued that these results constitute a challenge to traditional doctrine regarding price level determination, stating that "quantity-theoretic ideas can be quite misleading."

In this context, our main dissent from the FTPL position regarding about the consequences of the $R_{t}$ policy rule findings for standard theory is, as stated above, that the equilibria involved do not clash with key monetarist postulates. Instead, money and prices move together. This key point notwithstanding, it is true that there is, as Evans and Honkapohja (2004) establish, a competition between "monetarist" and "fiscalist"

\footnotetext{
${ }^{15}$ See Woodford (2003b) for a definition and discussion of the Taylor principle.
} 


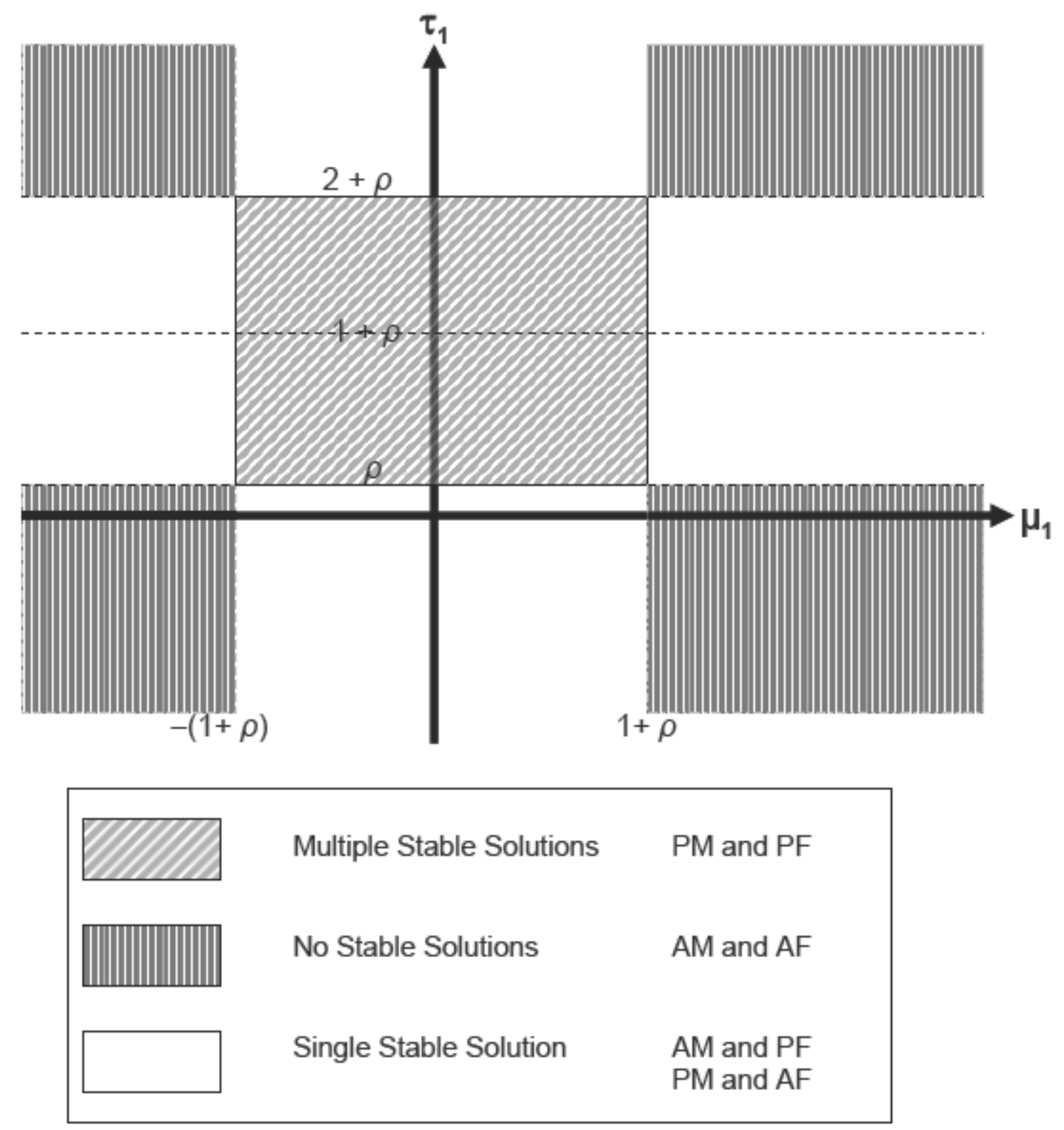

Figure 1. Solution outcomes for alternative fiscal/monetary policy combinations (Evans and Honkapohja, 2004) 
solutions in the interest-rate-rule case that parallels the competition between the two equilibria that occur in the constant-money-stock case. Those who, like Leeper (1991), favor the fiscalist solution tend to stress the need for monetary and fiscal policy coordination implied by that solution. And it is true, as we discuss below, that the role of coordination implied by the "fiscalist" solution does clash in certain respects with the baseline monetarist position concerning coordination as we have defined it in Section 4. Let us therefore discuss in detail specific aspects of the "monetarist" and "fiscalist" equilibria, and the conflicting conclusions on the role of coordination. We can then consider recent work on discriminating between the alternative equilibria.

We again assume the flexible-price, no-real-shock conditions that imply a constant real rate, so the Fisher equation is simply $R_{t}=r+\mathrm{E}_{t} \pi_{t+1}$. Let us suppress the constant $r$ as well as the intercept terms in the policy rules (16) and (17), and add a monetary policy shock to (16) so that it becomes $R_{t}=\mu_{1} \pi_{t}+e_{R t}$, with $e_{R t}$ white noise. Also, for the time being we assume that $\mu_{1}>0$. Then, as in Leeper (1991) and Evans and Honkapohja (2004), substitution of the monetary policy rule into the Fisher equation leads to a key equation describing inflation dynamics:

$$
\pi_{t}=\left(1 / \mu_{1}\right) \mathrm{E}_{t} \pi_{t+1}-\left(1 / \mu_{1}\right) e_{R t}
$$

From the minimum-state-variable perspective, this equation is sufficient to solve for inflation in the model. The equation constitutes a self-contained system, which one can solve forward to express inflation in terms of the single forcing process in the equation, the monetary policy shock $e_{R t}$. To that end, (18) can be solved forward as $\pi_{t}=$ $-\Sigma_{k=1}^{\infty}\left(1 / \mu_{1}\right)^{k} \mathrm{E}_{t} e_{R t+k-1}$. Thus, with $e_{R t}$ white noise, we have

$\pi_{t}=-\left(1 / \mu_{1}\right) e_{R t}$

Solution (19) is termed the "monetarist" solution by Evans and Honkapohja (2004) — the "monetarist" label being justified by the fact that the parameters and variables that appear in the monetary policy rule enter the solution expression, but those in the fiscal policy rule do not.

From the perspective of the FTPL literature, by contrast, equation (18) is not a selfcontained system; other equations in the model should be consulted and any other state variables that appear in those equations are candidates to appear alongside $e_{R t}$ in the 
solution expression for inflation. As the stock of government bonds $\left(b_{t}\right)$ appears in the government budget constraint, it constitutes an additional state variable, and the equilibrium expression for inflation becomes:

$\pi_{t}=K_{1} b_{t}+K_{2} e_{R t}$

where the $K_{i}$ are each functions of both monetary and fiscal rule parameters (again, see Evans and Honkapohja (2004) for the derivation of this solution). Thus we have two candidate equilibria, with different solution expressions for inflation: one in which inflation is a function of the monetary policy shock alone, and one where inflation depends both upon this shock and also on the quantity of bonds.

While money growth and inflation move together in all stable equilibria, and so reflect a key monetarist feature, the fiscalist solution (20) imposes a different implied hypothesis about the manner in which fiscal deficits are accommodated by monetary policy. Consider first the monetarist equilibrium. Note that under our flexible-price assumption, upward pressure on growth in nominal aggregate demand amounts to immediate inflationary pressure, and so the monetary policy rule (16) is in effect an interest-rate reaction to developments in aggregate nominal spending. ${ }^{16}$ In the monetarist equilibrium, the stronger the response to inflation in the policy rule, the greater the extent to which fiscal expansion is offset by reduced private spending. Thus ever more "active" monetary policy is progressively more successful at restraining the extent to which fiscal expansion triggers growth in nominal spending and money. Weaker responses (smaller $\mu_{1}$ values) allow fiscal expansion to have a greater effect on money growth. In the monetarist solution, therefore, a bond/money stock relationship will emerge, but will be a by-product of monetary policymakers' degree of permissiveness with respect to pressure on nominal spending growth. These features are reflected in the fact that inflation depends only on monetary policy shocks in the solution. The accommodation of deficits implied by permissive (or "passive”) policies with small $\mu_{1}$ values is reflected in the solution coefficient $-\left(1 / \mu_{1}\right)$ being larger (in absolute value) in those cases, reflecting less period-by-period control of inflation; that accommodation route does not imply an explicit fiscal term in the equilibrium expressions for money growth or inflation.

\footnotetext{
${ }^{16}$ Also, downward pressure on nominal demand amounts to undesired disinflationary pressure. The policy rule's objective is to keep inflation close to some target value, the latter being zero in the present example.
} 
The situation is quite different under the monetary accommodation process envisaged by the fiscalist solution. Here, accommodation of deficits is more automatic-influenced by the existence of the government budget constraint rather than governed by the interestrate rule alone. From equations (3) and (20), the expression for money growth in the fiscalist equilibrium is

$g^{m}{ }_{t}=\pi_{t}-\theta_{R} \Delta R_{t}=K_{1} b_{t}+\left(K_{2}-\theta_{R}\right) e_{R t}-K_{1} \mu_{1} \theta_{R} \Delta b_{t}-K_{2} \mu_{1} \theta_{R} \Delta e_{R t}$,

compared to the simpler expression in the monetarist equilibrium:

$g^{m}{ }_{t}=-\left(1 / \mu_{1}\right) e_{R t}-\theta_{R} \Delta e_{R t}$.

So the money growth expression in the monetarist equilibrium is simply a function of monetary policy rule and money demand coefficients. But in the fiscalist equilibrium it inherits additional terms involving fiscal-rule parameters, the bond stock, and the change in the bond stock. In the fiscalist equilibrium, under an interest-rate rule, strong responses in the interest-rate rule to aggregate demand pressure do not ensure control of the quantity of money and nominal spending. The FTPL amounts here to the result that, even when the monetary authority has a response to inflation in its interest-rate rule of its own choosing, the only way for it to have full control of the money stock is to control fiscal policy. Fiscal-monetary policy coordination is therefore necessary for inflation control, reflected in the appearance of the bond stock in the inflation solution (20).

The equilibria offered by the FTPL literature on interest-rate rules therefore arise from a particular vision of the process of monetary accommodation of government debt. In terms of our four-point characterization of monetarist doctrine in Section 4, these FTPL equilibria are fully reconcilable with proposition (II), but reflect some tension with respect to propositions (I), (III) and (IV). In particular, the fiscalist solution breaks the link between ever-more active interest-rate rules and ever-greater control of the money stock that exists under the monetarist solution, so that propositions (I) and (III) may not hold if "restrictive monetary policy” is defined as active interest-rate rule monetary policy. Consequently, the need for monetary-fiscal coordination would appear to be pressing, and not simply a manner of ensuring discipline on the part of the monetary authority, as was suggested by monetarist proposition (IV). It is therefore of importance to consider the relative plausibility of the monetarist and fiscalist solutions, and whether the monetarist postulates survive in that light. 
Much of the emphasis by FTPL supporters has been on conditions necessary for determinacy. Recently, however, there has been some redirection of emphasis toward the learnability of equilibrium in the sense of Evans and Honkapohja (2003), a property that is arguably necessary for the equilibrium to be regarded as plausible. ${ }^{17}$ Specifically, this is the position tacitly taken by Woodford (2003a). Since it is also the position of McCallum (2003a, 2003b), it seems to be emerging as one on which some pro-FTPL and anti-FTPL analysts can agree.

In McCallum (2003a), the cases considered are ones with a money stock instrument, and it is found that the monetarist solution is learnable whereas the FTPL one is not. A more rigorous analysis of the same type is developed by Evans and Honkapohja (2004), who use a fully specified nonlinear model and obtain the same results. Also, they take up Woodford's (2003a) objection, that the exclusion of $b_{t}$ from the list of state variables biases the outcome, and reject it.

Woodford (2003a) argues, however, that the FTPL examples with $R_{t}$ and $b_{t}$ as the policy instruments are more important than examples with a money stock rule. In that regard, as noted above, Evans and Honkapohja (2004) also consider the Leeper (1991) rules, using in this case a linearized model. They examine only cases in which $\mu_{1}>0$ and $\tau_{1}>0$, because other values imply perverse policy. Also, they assume $\tau_{1}<1+\rho$ because the $1+$ $\rho<\tau_{1}$ case would (around the steady state) retire all debt in one period.

Their results are summarized in Figure 2, based on their figure but with additional labels that we discuss presently. ${ }^{18}$ The results establish that, for the most part, the learnability criterion is consistent with Leeper's determinacy results, so that in an activemoney/passive-fiscal regime (AM/PF) the "monetarist" solution is learnable and the "fiscalist" solution is not, whereas in an active-fiscal/passive-money regime the fiscalist solution is learnable (and the monetarist solution is not), and in a passive-money/passivefiscal regime neither solution is learnable. In the case of the active-money/active-fiscal regime with $0<\tau_{1}<\rho$ and $\mu_{1}>1+\rho$, however, Evans and Honkapohja (2004) find that

\footnotetext{
${ }^{17}$ See Bullard and Mitra (2002) for an early application of the learnability criterion to monetary policy rules, and McCallum (2003b) for an argument that least-squares learnability should be considered necessary (not sufficient) for a solution to be regarded as plausible.

${ }^{18}$ The unnumbered regions in Figure 2 are those where no learnability results are reported by EH, owing to their focus on fiscal rules that satisfy the aforementioned restriction $\tau_{1}<(1+\rho)$.
} 


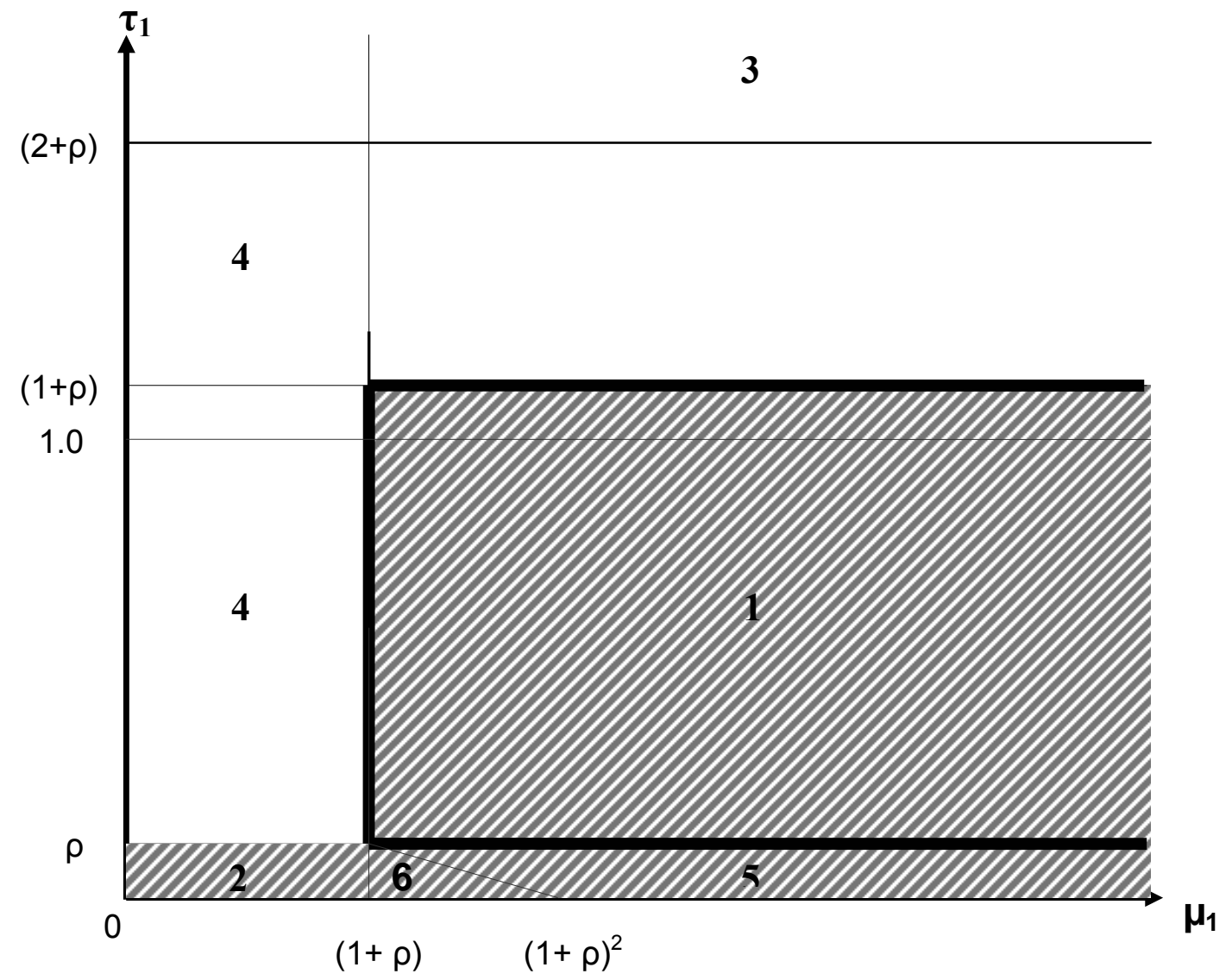

1: Monetarist solution prevailsstationary outcomes

2: Fiscalist solution prevailsstationary outcomes

3: No stable solutions

4: No learnable solution

5: Monetarist solution prevailsprices, money stationary; bond stock explodes

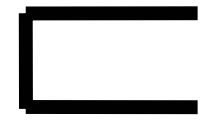

Region of "sensible" policy combinations

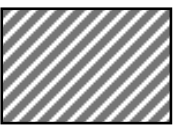

Money and prices move together in learnable equilibrium

6: Fiscalist solution prevailsmoney, bonds, prices explode

Figure 2. Classification of Evans and Honkapohja's (2004) learnability results 
there is a very small set of policy-rule parameter combinations for which the fiscalist solution is learnable - again, see Figure 2-and a small but much larger set for which the monetarist solution is learnable. In fact, the monetarist solution is learnable for all $\mu_{1}$ greater than $(1+\rho)^{2}$ in this region. And the monetarist solution features inflation that is stable around the monetary authority's target value. Thus even with the fiscal irresponsibility implied by fiscal responses in the range $0<\tau_{1}<\rho$, a resolute central bank can have its way with regard to inflation. It should be noted that advocates of the FTPL regard this "monetarist" outcome as the appropriate equilibrium in this case; this is so because while the "fiscalist" equilibrium gives greater weight to fiscal policy in determining the price level, just as in the FTPL, it also implies explosive real bond stock behavior, contradicting the FTPL (see Woodford, 2003a, p. 1185). ${ }^{19}$ But the fact remains that a major message of traditional monetary analysis is confirmed by the learnability of the monetarist equilibrium, a message in line with the Friedman statement given earlier that "monetary policy can curb inflation" and does not need "to be backed up by fiscal policy at all."

There are some aspects of the Evans-Honkapohja (2004) results that might appear to be inconsistent with traditional monetarist teachings; there is, for example, a sizable region of policy parameter values (with both policy rules passive) in which there is no equilibrium that is learnable. (This corresponds to region "4” in Figure 2.) But actually that finding does not refute monetarist analysis. Normative monetarist analysis was invariably expressed in terms of policy rules for control of the money supply, not shortterm interest rates. In the monetarist equilibrium, rule (16) delivers a constant money growth rule in the limit as $\mu_{1}$ approaches infinity. Thus these non-learnable equilibria can be replaced by a learnable equilibrium by taking this limit and substituting a money stock rule for an interest-rate rule. The message for monetary policy from the non-learnable region is that interest-rate rules with high but finite $\mu_{1}$ do not always reproduce some of the desirable properties of a money stock rule. ${ }^{20}$

In any event, the main conclusion for the issue of fiscal-monetary coordination is as follows. Suppose that both monetary and fiscal policymakers are behaving sensibly, i.e., that the central bank is following an interest-rate rule such as (16) with $\mu_{1}>1+\rho$ and the

\footnotetext{
19 The nominal bond stock explodes in the monetarist equilibrium too, but does so at rate slow enough that the growth of the real bond stock satisfies intertemporal solvency of the government; see Evans and Honkapohja (2004, p. 21).

${ }^{20}$ And both monetarist and fiscalist equilibria in this region, while not learnable, invariably feature close links between money stock and the price level, in line with the positive analysis in monetarist doctrine.
} 
fiscal authority is setting tax rates as in (17) with $\rho<\tau_{1}<1+\rho$. Then for any value of these policy parameters within this specified "sensible" region, there is a unique rational expectations solution that is learnable, and it is the monetarist solution. Thus the behavior of inflation is in these cases determined by the central bank's policy rule, regardless of the setting of $\tau_{1}$ in the fiscal rule. Accordingly, there is no need for policy coordination; neither policy authority needs to take the details of the other's rule into account in designing its own (sensible) policy rule.

With the preceding discussion and that of Section 4 in mind, we are now in a position to reconsider Woodford's (2001, p. 684) arguments that interest-rate rules deliver results contrary to the message of the quantity theory. Woodford notes that an interest-rate peg alongside government debt growth is associated with increases in both the money stock and prices. But he argues that this is inconsistent with the "principle ... [of] inflation determination" of monetarist analysis because "the price level may rise... simply because [fiscal developments] are expected" and that "a mechanical connection between the government budget and the monetary base is not at work.” But neither of these positions is inconsistent with monetarist doctrine: as we noted, monetarists cited as a "major reason" for deficit-money connections the "roundabout" or "indirect” monetization of deficits via an interest-rate stabilization policy, rather than a direct, mechanical monetization; and they cited expectations of future deficits as a source of inflationary expectations, provided these also triggered expectations of higher future money growth. In addition, Woodford (2001, p. 684) states that “inflation cannot really be explained” by the quantity theory in this case because the closeness of the money stock and price level paths reflects the increased demand by agents for more nominal money in line with the higher price level. This, however, is simply a statement that agents are on their money demand curve, and that the interest-rate rule makes the money supply function elastic. Both of these properties are consistent with monetarist predictions; and neither property gives money a diminished (or enhanced) status relative to the role it has in the study of interest-rate rules in other, non-FTPL contexts. Or to put it somewhat differently, the monetarist explanation of inflation describes how private agents' behavior determines inflation in response to government policy rules; and the structural equations describing private sector behavior are the same whether the central bank follows a money supply or interest-rate rule.

The crucial condition, for the validity of the monetarist explanation of inflation, is that alternative monetary policy rule settings could have insulated the money stock path from 
the effect of the growth in government debt, and thereby also contained the price level path. As we have seen, this condition is met in the "monetarist" equilibria under interestrate rules, though not in the fiscalist equilibria. The issue thus again boils down to the choice between the candidate equilibria; and we have argued that it is the monetarist solution that has greater merit in the vast majority of policy-relevant cases.

\section{The FTPL and the cashless economy}

Expositions of the FTPL have occasionally been conducted in models that use Woodford's (2003b, Ch. 2) “cashless limit” economy, i.e., an economy in which advances in payments technology have made private agents’ demand for real money balances negligible, so that virtually none of the economy's transactions are carried out using money. ${ }^{21}$ We argue here that these two model features-FTPL and the cashless economy-together represent a combination that is unlikely to generate useful or genuinely interesting conclusions. ${ }^{22}$

FTPL results and cashless-economy setups have both been advanced as departures from orthodox analysis, but the former are actually less striking in the presence of the latter. The FTPL has been invoked as nonstandard precisely because it produces a different explanation for inflation from the quantity theory of money. The quantity theory describes the inflation process in terms of the adjustment by private agents to increases in the nominal money stock that are excessive in relation to their demand for real balances. ${ }^{23}$ The role that contractions in the agents' demand for money make to sustained inflations in this account is confined to contractions that are an endogenous response to expansions of supply. The FTPL, by contrast, provides a channel whereby ongoing contractions in agents' demand for money occur endogenously, even in unchanged supply conditions. It is, therefore, hardly a good basis for demonstrating the novelty of the FTPL to adopt a modeling environment—-the cashless limit—in which agents' demand for real money balances has already been eliminated exogenously.

The conflict between promoting the FTPL and using cashless-economy assumptions can also be illustrated through an analogy with Ricardian equivalence. As we noted in the

${ }^{21}$ See for example Woodford (2001, p. 684) and Cochrane (2005).

${ }^{22}$ See McCallum (2003a, Sect. VI) for an earlier, complementary, and more extensive set of arguments.

${ }^{23}$ As noted earlier, this account of inflation does not require that agents move off their money demand curve; rather, money growth is considered excessive because it exceeds the increase in nominal balances that agents would have demanded under ongoing price stability. 
introduction, imposing conditions which usually lead to satisfaction of Ricardian equivalence is the appropriate starting point for promoting the FTPL. For then the importance of fiscal policy (in particular, of government debt) can potentially be demonstrated in an environment that typically minimizes the importance of fiscal policy for macroeconomic developments. By the same token, the relative unimportance of monetary policy in the FTPL is ideally demonstrated in a standard model in which orthodox results on the importance of monetary policy for price level determination would usually prevail. To use a cashless-economy setup, by contrast, is to start with a model that is nonstandard from the point of view of monetary analysis, so violations of standard results are less compelling. In particular, results that highlight the importance of the stock of government debt for price level determination are not dramatic in an environment in which the financial stock typically relevant for price level dynamicsmoney - has been removed from the economy, or has been deprived of its traditional medium-of-exchange properties.

\section{Conclusions}

In this paper we have discussed the properties and plausibility of two versions of the fiscal theory of the price level (FTPL) — one variant in which monetary policy rules are cast in terms of the nominal money stock and the other with nominal interest-rate rulesas compared with the theory of price level behavior offered by standard monetarist doctrine. The FTPL under interest-rate rules is dissimilar to the FTPL under money stock rules, in that the former's implications do not violate the monetarist property that the general price level and the nominal money stock move together in equilibrium. The FTPL variants under the two rule types do share the characteristic that they generate equilibria where, in contrast to the monetarist equilibrium, an extra state variable appears in the solution expression for inflation. The effect of this extra term is to make inflation a function of the fiscal policy rule, whereas under the monetarist equilibrium inflation is a function of the monetary policy rule alone.

The channel through which this extra term appears in the inflation expression differs across the FTPL-with-money-stock-rule and FTPL-with-interest-rate-rule variants. In the former case, the extra term enters price level dynamics for a given nominal money stock,

so that money and prices diverge. In the latter case, the extra term (the bond stock) enters the equilibrium expressions for both money growth and inflation, so that the two series do not diverge (nor do the log levels of money and prices). The FTPL under a money 
stock rule is therefore strongly nonmonetarist in disconnecting money growth and inflation. The FTPL under an interest-rate rule is less strongly nonmonetarist, as money growth and inflation do move together in equilibrium, but does postulate that government bonds may trigger monetary accommodation even when the monetary authority follows a disciplined interest-rate rule. This property is in conflict with monetarists' claims that indirect accommodation of deficits arises solely via interest-rate stabilization by central banks, and so implies that vigorous interest-rate responses can disconnect government debt from money creation. FTPL modeling with interest-rate rules can thus be regarded as offering a description of the monetary accommodation process that clashes with some typical monetarist propositions, but which still leads to a close money/prices relationship.

Of the two versions of the FTPL, the one with a money stock rule clearly implies irreconcilable differences with monetarist doctrine, due to its allowance for unbounded divergences between money and prices. The FTPL with interest-rate rules differs from monetarist doctrine, but does so to a lesser extent, limited to issues involving the accommodation process. When used as a means of choosing between the FTPL and monetarist equilibria, the learnability criterion tends to favor the latter. The main messages for practical policy are ${ }^{24}$ that central banks can control inflation irrespective of fiscal policy and that detailed coordination between monetary and fiscal authorities is not needed for effective macroeconomic policy.

\footnotetext{
${ }^{24}$ Under the assumed absence of distorting taxes and with finite planning horizons.
} 


\section{References}

Arce, Oscar J. (2004). "The Fiscal Theory of the Price Level under a Price-Invariant Nominal Money Supply Rule: What Went Wrong?” Manuscript, Bank of Spain.

Arce, Oscar J. (2005). “The Fiscal Theory of the Price Level: A Narrow Theory for NonFiat Money.” Bank of Spain Working Paper No. 0501.

Brunner, Karl (1969). “The Drift into Persistent Inflation,” Wharton Quarterly, Fall 1969, 23-36. Reprinted in T. Lys (ed.), Monetary Theory and Monetary Policy: The Selected Essays of Karl Brunner, Volume Two. Cheltenham, U.K.: Edward Elgar, 1997. $142-151$.

Brunner, Karl (1975). “Monetary Policy and Monetary Control in 1975.” Statement to U.S. Senate Banking, Housing and Urban Affairs Committee, April 30. In The Conduct of Monetary Policy Pursuant to House Concurrent Resolution 133. Washington, DC: Government Printing Office. 87-100.

Brunner, Karl (1976). “Inflation, Money and the Role of Fiscal Arrangements.” In M. Monti (ed.). The “New Inflation” and Monetary Policy. London: Macmillan. 25-61.

Brunner, Karl (1977). “Statement on Monetary Policy.” Testimony prepared for the U.S. House of Representatives Committee on Banking and Finance, February 4. In Conduct of Monetary Policy. Washington, DC: Government Printing Office. 153-175.

Brunner, Karl (1980). “Another View at Fashionable Fallacies.” Shadow Open Market Committee Position Paper, February 4. Reprinted in T. Lys (ed.), Monetary Theory and Monetary Policy: The Selected Essays of Karl Brunner, Volume Two. Cheltenham, U.K.: Edward Elgar, 1997. 92-96.

Brunner, Karl (1986). “Fiscal Policy in Macro Theory: A Survey and Evaluation.” In R.W. Hafer (ed.), The Monetary versus Fiscal Policy Debate: Lessons from Two Decades. Totowa, N.J.: Rowman and Allenheld. 33-116. 
Brunner, Karl, and Allan H. Meltzer (1975). "Fiscal Policy, Inflation and the Price Level.” Paper presented at conference on “Monetary Mechanisms in Open Economies,” Helsinki, August 1975.

Brunner, Karl, and Allan H. Meltzer (1993). Money and the Economy: Issues in Monetary Analysis. Cambridge, U.K.: Cambridge University Press.

Buiter, Willem H. (2002). “The Fiscal Theory of the Price Level: A Critique,” Economic Journal, Vol. 112(481), 459-480.

Bullard, James B., and Kaushik Mitra (2002). “Learning about Monetary Policy Rules,” Journal of Monetary Economics, Vol. 49(6), 1105-1129.

Cagan, Phillip (1956). “The Monetary Dynamics of Hyperinflation.” In M. Friedman (ed.), Studies in the Quantity Theory of Money. Chicago: University of Chicago Press. 25-117.

Carlstrom, Charles T., and Timothy S. Fuerst (2000). "The Fiscal Theory of the Price Level,” Federal Reserve Bank of Cleveland Economic Review, Vol. 36(1), 22-32.

Christiano, Lawrence, and Terry J. Fitzgerald (1999). Understanding the Fiscal Theory of the Price Level," Federal Reserve Bank of Cleveland Economic Review, Vol. 36(2), $1-37$.

Cochrane, John (2005). “Money as Stock,” Journal of Monetary Economics, Vol. 52(3), 501-528.

Evans, George W., and Seppo Honkapohja (2003). Learning and Expectations in Macroeconomics. Princeton: Princeton University Press.

Evans, George W., and Seppo Honkapohja (2004). "Policy Interaction, Learning and the Fiscal Theory of Prices.” Manuscript, University of Oregon.

Friedman, Milton (1970). “A Theoretical Framework for Monetary Analysis,” Journal of Political Economy, Vol. 78(2), 193-238. 
Friedman, Milton (1978a). “Inflationary Recession,” Newsweek, April 24, 81.

Friedman, Milton (1978b). Tax Limitation, Inflation and the Role of Government. Dallas: Fisher Institute.

Friedman, Milton (1981). “Deficits and Inflation,” Newsweek, February 23, 44.

Friedman, Milton (1984). “Why Deficits Are Bad,” Newsweek, January 2, 56.

Friedman, Milton (1987). “Quantity Theory of Money.” In J. Eatwell, M. Milgate, and P. Newman (eds.), The New Palgrave: A Dictionary of Economics, Volume 4, Q to Z. London: Macmillan. 3-20.

Friedman, Milton, and Anna J. Schwartz (1963). A Monetary History of the United States, 1867-1960. Princeton: Princeton University Press.

Gordon, David B., and Eric M. Leeper (2005). “The Price Level, the Quantity Theory of Money, and the Fiscal Theory of the Price Level.” Manuscript, Indiana University.

Kocherlakota, Narayana and Christopher Phelan (1999). "Explaining the Fiscal Theory of the Price Level,” Federal Reserve Bank of Minneapolis Quarterly Review, Vol. 33(4), $14-23$.

Larsen, Colin (1981). “Friedman Advises: 'Don’t Blame the Politicians for Everything,'” New Zealand Herald, April 18, Section 1, 12.

Leeper, Eric M. (1991). “Equilibria under 'Active’ and 'Passive’ Monetary and Fiscal Policies,” Journal of Monetary Economics, Vol. 27(1), 129-147.

McCallum, Bennett T. (1983). “On Non-Uniqueness in Rational Expectations Models: An Attempt at Perspective,” Journal of Monetary Economics, Vol. 11(2), 139-168.

McCallum, Bennett T. (1999). “Issues in the Design of Monetary Policy Rules.” In J. B. Taylor and M. Woodford (eds.), Handbook of Macroeconomics, Vol. 1C. Amsterdam: North Holland. 1483-1530. 
McCallum, Bennett T. (2001). "Indeterminacy, Bubbles, and the Fiscal Theory of Price Level Determination,” Journal of Monetary Economics, Vol. 47(1), 19-30.

McCallum, Bennett T. (2003a). "Is the Fiscal Theory of the Price Level Learnable?,” Scottish Journal of Political Economy, Vol. 50(6), 634-649.

McCallum, Bennett T. (2003b). "Multiple-Solution Indeterminacies in Monetary Policy Analysis,” Journal of Monetary Economics, Vol. 50(6), 1153-1175.

McCracken, Paul W. (1950). “The Present Status of Monetary and Fiscal Policy,” Journal of Finance, Vol. 5(1), 24-48.

Meltzer, Allan H. (1976). “Statement on Monetary Policy, June 24, 1976.” In U.S. House of Representatives Committee on Banking, Currency, and Housing, Ending Inflation: The Next Steps. Washington, DC: Government Printing Office. 178-180.

Meltzer, Allan H. (1977). “It Takes Long-Range Planning to Lick Inflation,” Fortune, December, 96-104.

Meltzer, Allan H. (1984). “Deficits and Inflation.” In A.T. Sommers (ed.), Reconstructing the Federal Budget: A Trillion Dollar Quandary. New York: Praeger. 117-129.

Niepelt, Dirk (2004). “The Fiscal Myth of the Price Level,” Quarterly Journal of Economics, Vol. 119(1), 277-300.

Sargent, Thomas J., and Neil Wallace (1973). "Rational Expectations and the Dynamics of Hyperinflation,” International Economic Review, Vol. 14(2), 328-350.

Sargent, Thomas J., and Neil Wallace (1981). “Some Unpleasant Monetarist Arithmetic,” Federal Reserve Bank of Minneapolis Quarterly Review, Vol. 5(1), 1-17.

Schwartz, Anna J. (1985). “Where the Bank Went Wrong,” The Banker, Vol. 135(708), $100-101$. 
Shadow Open Market Committee (1980). "Policy Statement of the Shadow Open Market Committee.” September 22. Reprinted in A.H. Meltzer, Money, Credit, and Policy. Cheltenham, U.K.: Edward Elgar, 1995. 380-386.

Sims, Christopher A. (1994). "A Simple Model for Study of the Determination of the Price Level and the Interaction of Monetary and Fiscal Policy,” Economic Theory, Vol. 4(3), 381-399.

Walsh, Carl E. (2003). Monetary Theory and Policy. Cambridge, MA: MIT Press. 2nd edition.

Woodford, Michael (1994). "Monetary Policy and Price Level Determinacy in a Cashin-Advance Economy,” Economic Theory, Vol. 4(3), 345-380.

Woodford, Michael (1995). "Price level Determinacy without Control of a Monetary Aggregate,” Carnegie-Rochester Conference Series on Public Policy, Vol. 43(1), 1-46.

Woodford, Michael (2001). “Fiscal Requirements for Price Stability,” Journal of Money, Credit and Banking, Vol. 33(3), 669-728.

Woodford, Michael (2003a). “Comment on 'Multiple-Solution Indeterminacies in Monetary Policy Analysis,'” Journal of Monetary Economics, Vol. 50(6), 1177-1188.

Woodford, Michael (2003b). Interest and Prices: Foundations of a Theory of Monetary Policy. Princeton: Princeton University Press. 